\title{
INVESTMENT TAX INCENTIVES, PRICES, AND THE SUPPLY OF CAPITAL GOODS*
}

\author{
Austan Goolsbee
}

Using data on the prices of capital goods, this paper shows that much of the benefit of investment tax incentives does not go to investing firms but rather to capital suppliers through higher prices. A 10 percent investment tax credit increases equipment prices 3.5-7.0 percent. This lasts several years and is largest for assets with large order backlogs or low import competition. Capital goods workers' wages rise, too. Instrumental variables estimates of the short-run supply elasticity are around 1 and can explain the traditionally small estimates of investment demand elasticities. In absolute value, the demand elasticity implied here exceeds 1 .

\section{INTRODUCTION}

Investment is of paramount importance for both business cycle fluctuations and long-term economic growth, so it is not surprising that the United States has repeatedly changed depreciation allowances, corporate tax rates, and the investment tax credit (ITC) in an effort to stimulate it. Although there appears to be an abiding faith among policy-makers that tax incentives can influence the investment decisions of firms and serve as a tool for stabilizing the economy, empirical evidence for the connection is weak. Econometric research has commonly found that tax policy and the cost of capital have little effect on real investment. Economic theory predicts that the marginal user cost of capital should be the primary determinant of investment demand, but actual estimates of the price elasticity of investment using standard models such as Auerbach and Hassett [1990, 1992], Kopcke [1982], or Chirinko, Fazzari, and Meyer [1996] mostly lie between zero and -.4 and much of the response enters with a lag. Studies looking solely at the tax portion of the cost of capital, in order to get around measurement error issues, usually find the

* I wish to thank James Poterba, Olivier Blanchard, Avinash Dixit, Kevin Hassett, Jerry Hausman, James Hines, Lawrence Katz, Steven Levitt, Maggie Newman, Jack Porter, Robert Pindyck, David Scharfstein, Robert Solow, an anonymous referee, and seminar participants at the University of California at Berkeley, Columbia University, the University of Chicago, Harvard University, Northwestern University, the University of Michigan, Princeton University, Stanford University, the Wharton School of the University of Pennsylvania, and Yale University for helpful comments. I also wish to thank Dale Jorgenson for providing tax data by asset and the National Science Foundation for financial support. This article was part of my dissertation at the Massachusetts Institute of Technology.

(C) 1997 by the President and Fellows of Harvard College and the Massachusetts Institute of Technology.

The Quarterly Journal of Economics, August 1997 
same small effects and important lags. ${ }^{1}$ The evidence that investment is only modestly responsive to price has been one of the most robust findings of the empirical investment literature and has led many to conclude that investment demand is not very price sensitive, at least in the short and medium run.

This paper presents evidence for an alternative explanation of the low estimated response of real investment to changes in the cost of capital and for the importance of lagged policy variables. The hypothesis is that the supply of capital goods is upward sloping in the short run so there is an external cost of adjusting the capital stock in response to tax changes. Investment demand is actually very responsive to investment tax policy but in the short run the increased demand for investment mainly increases capital goods prices rather than quantities. A large part of the subsidy's reduction of the effective purchase price of equipment is simply lost to the capital suppliers.

This argument was raised at least as far back as the 1969 debate in the Joint Economic Committee over the ITC where representative Henry Reuss of Wisconsin asked the Secretary of the Treasury if he "had truly considered the impact of the 7-percent investment tax credit which, in addition to costing the treasury some $\$ 3$ billion a year in revenues, produces an inflationary overheating of the capital equipment market." ${ }^{2}$ The results presented below will demonstrate that the content of Rep. Reuss's comment actually has quite important implications for the study of investment.

At the outset, three facts motivate any discussion of investment tax subsidies. The first is their substantial revenue cost. Before its final repeal in 1986, for example, the ITC cost around $\$ 30$ billion per year in 1994 dollars, one of the single largest tax expenditures. Accelerated depreciation allowances have also been extremely costly. Whatever the benefits of investment subsidies, they must be weighed against these costs.

The second fact is that, politically, some of the primary lobbyists in favor of investment subsidies are the producers of

1. Bosworth [1985], Clark [1993], and the survey in Gravelle [1992] find small effects of tax policy on real investment. Gordon and Jorgenson [1975] and Clark [1993] find that the response has a delay of at least one to two years. Cummins, Hassett, and Hubbard [1994] argue that measurement error exists in the tax term, as well, and that correcting for it with a "natural experiments" approach on cross-sectional data puts the investment elasticity closer to -.66. Chirinko, Fazzari, and Meyer [1996] correct for measurement error in similar data and find a smaller elasticity, but they lack the natural experiments approach.

2. Reported in King [1993]. 
capital equipment. ${ }^{3}$ Nor is their love of tax subsidies for nought. Lyon [1986] has shown that the stock prices of various types of equipment manufacturers respond more positively to the announcement of investment subsidies than their capital intensities suggest they should. Indeed, under the Nixon and Ford administrations one of the stated goals for increasing the investment tax credit was to make domestic machine tool and other equipment manufacturers more profitable. If the conventional view of investment demand is correct, this intensive lobbying behavior is hard to explain since changes to tax subsidies ought to have little effect on real investment and no effect on price.

The third important fact is that policy-makers in the United States repeatedly change investment tax policy. In the entire 30-year sample from 1959 to 1988, Congress never left the tax portion of the cost of capital unchanged for more than four years. Because of this, short-run asset price effects are of first-order importance. Conventional steady-state-type analysis is not appropriate in such a setting and can lead to inaccurate results. ${ }^{4}$

For evidence, I use data on the prices of capital equipment goods compiled by the Bureau of Economic Analysis (BEA) and link them to the corresponding tax price for each asset type. The results suggest that capital goods prices rise significantly in response to changes in tax subsidies. Reduced-form estimates indicate that a 10 percent tax credit increases the price by 3.5 percent to 7 percent overall, and close to 10 percent for several types of assets. The results are highly robust. Additional results show that the price increases are largest where there are capacity constraints or low imports and that the wages of production workers in capital goods industries rise with the subsidies, as well. Actual estimates of the supply elasticity center around 1 and imply that the true elasticity of investment demand exceeds 1 in absolute value.

An upward-sloping supply curve for capital raises troubling questions about whether tax policies intended to stimulate investment or stabilize economic fluctuations simply create short-run windfall gains for capital suppliers. If the value of tax subsidies is capitalized into prices, then the principal lesson of tax incidence

3. For a political history of investment tax policy, see King [1993].

4. The focus on short-run price effects places this study in the tradition of the asset market approach in public finance which has concerned tax-induced asset price changes to well-defined asset markets like land, housing, and the stock market: see Feldstein [1977], Summers [1983], Poterba [1984], or Cutler [1988]. 
analysis - that paying a tax and bearing the burden of a tax are not the same-holds equally well for tax subsidies.

The paper begins with a discussion about the theory of upwardly sloping supply curves for capital in Section II and a discussion about the data and estimation strategy in Section III. Next, Section IV presents reduced-form evidence demonstrating the significant effect of investment policy on the price of capital which implies that the supply curve cannot be flat. Section V shows that these results are robust to alternative explanations. Section VI examines the duration of the price increases and the incidence of the subsidies. Section VII examines the causes of the price increases. Section VIII uses taxes as an instrument to actually estimate the supply curve for capital equipment. The paper concludes with a discussion of why a rising supply curve is important for the analysis of investment.

\section{MODEL}

In the standard cost of capital model of Hall and Jorgenson [1967], the firm has a demand for capital and invests until the marginal product equals the user cost of capital. It has been pointed out by Lucas [1967], Abel [1978], and others that the standard cost of capital model requires adjustment costs to explain why investment is not infinite. Normally these adjustment costs are thought of as internal to the firm, as in the " $q$ " theories of investment. When analyzing the impact of tax policy, however, it may be important to consider the impact of external adjustment costs, as well. Estimates from tax-adjusted $q$ models that assume capital goods prices to be exogenous are not appropriate for evaluating the effect of tax subsidies when the capital supply curve is upward sloping because such subsidies change relative prices.

This paper starts with the hypothesis that the marginal costs of producing capital goods are rising in the short run so the supply curve is not perfectly elastic. ${ }^{5}$ This is a natural assumption, and it underlies the work of Foley and Sidrauski [1970], Mussa [1977], and part of the discussion of investment in Romer [1996]. In these models, the price of capital goods must adjust to clear the market

5. Goolsbee [1995] shows that even if marginal costs are constant so the supply curve is flat, under certain conditions, imperfect competition in capital goods industries can lead markups to rise in response to investment subsidies, giving the same implications for investment. 
at all times which implies that shifts in the demand for capital will raise prices in the short run to keep the demand equal to the existing stock. Firms must balance their desire for more capital with the higher costs of purchasing that capital so they smooth investment over time. Such models have been empirically estimated in the work of Poterba [1984] and Rosen and Topel [1988] on housing investment.

This paper uses a standard model based on Poterba [1984] which generates distinct short- and long-run implications for investment and prices and clearly motivates the empirical work on the subject. ${ }^{6}$ Let the demand for capital services, $K_{D}$, be a function of the rental price of capital, $R . K_{D}=f(R)$, where $f^{\prime}<0$. If the supply of capital services is a monotonic function of the capital stock, then the inverse demand curve for capital can be expressed as $R=R(K)$, where $R^{\prime}<0$. As usual, the firm's demand for capital services increases until $R(K)=c$, where

$$
c=\frac{\left(r+\delta-\pi_{k}\right)(1-I T C-\tau z)}{1-\tau} \cdot p,
$$

the Jorgensonian cost of capital. The rate of depreciation for capital is $\delta$, the interest rate $r$, the sale price of capital goods $p$, the rate of investment tax credit ITC, the corporate tax rate $\tau$, the present value of depreciation allowances $z$, and the expected capital gain in the price of capital goods $\pi_{k}$. Since $\pi_{k}=\dot{p} / p$, the first-order condition can be rewritten as

$$
\dot{p}=-R(K) \cdot \frac{1-\tau}{1-I T C-\tau z}+(r+\delta) \cdot p,
$$

and $\dot{p}=0$ gives the steady state demand for capital. Investment $I$ is the output of the capital goods-producing sector and is a function of the capital goods price, $I=g(p)$. This means that

$$
\dot{K}=I-\delta K=g(p)-\delta K,
$$

and the steady state price can then be defined as $p^{*}=g^{-1}(\delta K)$.

This setup is displayed in Figure I, a traditional phase diagram for the system. When the tax subsidy is enacted, the $\dot{p}=$ 0 curve facing the supplier shifts from $D$ to $D^{\prime}$. This graph can illustrate how taxes are used, in the standard empirical literature, to identify the elasticity of investment demand using

6. This model is similar to the $q$ investment models in Summers [1981] and Abel [1982]. 


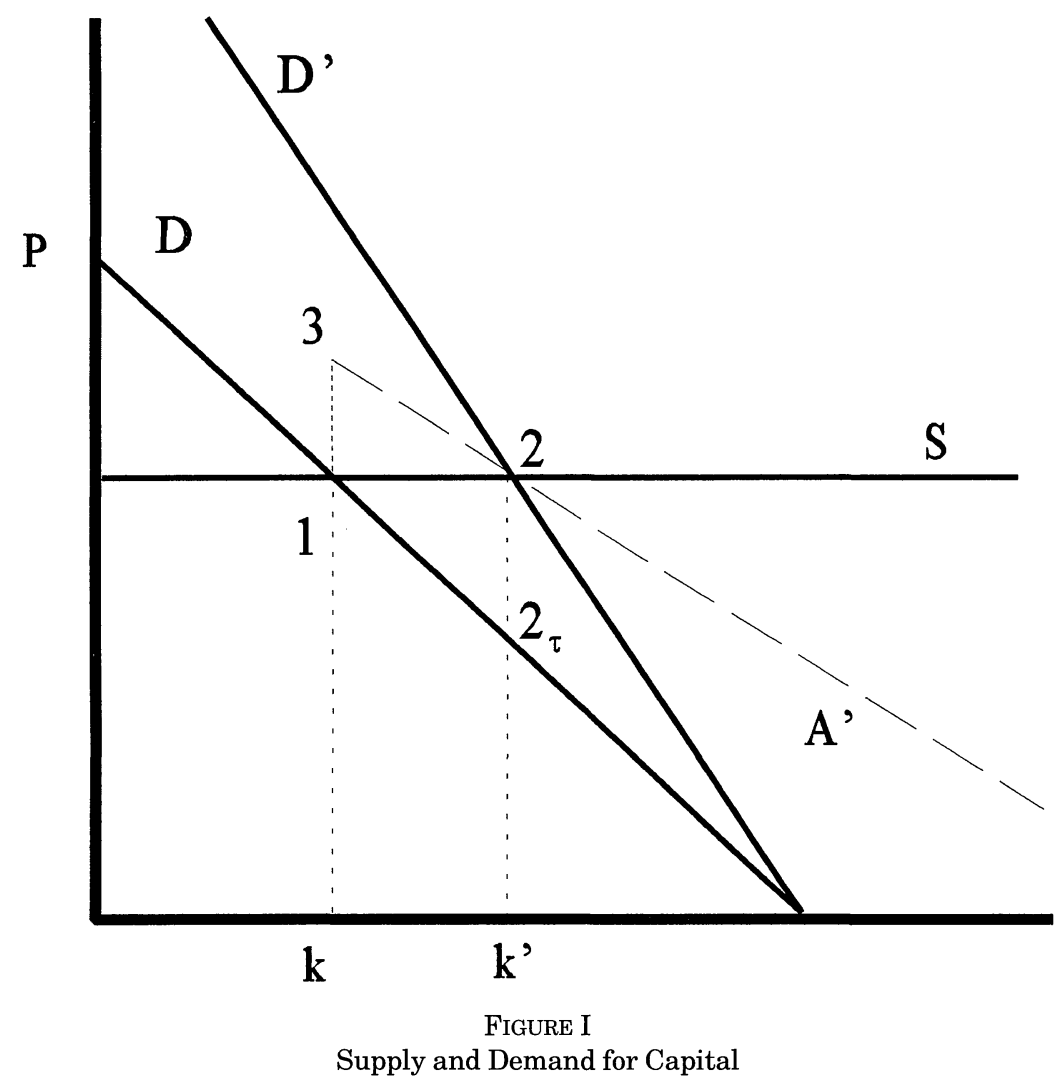

comparative static analysis of steady states. Essentially, the data give the original demand for capital (at point 1 ), $k$, and then the demand after a tax change (at point 2), $k^{\prime}$. Then assuming a perfectly elastic supply curve and a steady state, it is easy to calculate the after-tax price facing the buyer since it is simply the old price reduced by exactly the amount of the subsidy (at point $2_{\tau}$ ). Point 1 and point $2_{\tau}$ are two points on a demand curve that can be used to figure out an elasticity of demand.

Even if the long-run supply is perfectly elastic, however, the short-run supply of investment goods here is not. When a subsidy takes effect, the first thing that happens is not capital increasing to point 2; instead capital goods prices first rise to point 3 , and then only slowly does capital increase along the new stable arm 
$A^{\prime}$. For a temporary tax change, which, in practice has been all of them, prices will still rise initially but capital will return to the original level before it ever reaches the new equilibrium. This makes statistical inference on long-run effects particularly problematic.

This theoretical model has important implications for empirical studies of investment. Indeed, it can potentially explain the three empirical puzzles of the investment literature. First, the price jump can explain why capital producers support investment subsidies more than their capital intensities suggest they should. Second, the path along the stable arm to the new equilibrium takes time and can explain why lags are important. Third, and most important, the upward-sloping supply creates a classic simultaneity problem and leads the standard approach to underestimate the true elasticity of demand. The problem is even worse for temporary tax changes because the economy never reaches the new steady state and thereby confounds estimation of the longrun impact.

To see the bias toward zero in the standard approach, take a simplified version of an investment demand equation (in logs):

$$
I_{D}=\alpha+\beta(\operatorname{Tax})+\beta\left(P_{\mathrm{k}}\right)+\epsilon,
$$

where investment demand is a negative function of the taxadjusted price of capital. Interest and depreciation are fixed so they are part of the constant, and $\epsilon$ is an error term. The standard estimate in the literature looks at the response of investment to a change in the tax term, $d\left(I_{D}\right) / d(\operatorname{Tax})$, and assumes that prices are exogenous (i.e., supply curve is flat). In this case, $d\left(I_{D}\right) / d(\operatorname{Tax})$ is, indeed, equal to the true elasticity of demand $\beta$. If the supply of capital is upward sloping, however, so that reducing the tax term increases prices, then including the price term as an exogenous variable is invalid. In that case, the price change will be an omitted variable in the error term, so $d\left(I_{D}\right) / d(\operatorname{Tax})$ will no longer equal the true elasticity $\beta$. Instead, as in a standard omitted variable bias calculation, it will equal

$$
B=\frac{d\left(I_{D}\right)}{d(\operatorname{Tax})}=\beta\left[1+\frac{\partial p}{\partial(\operatorname{Tax})}\right],
$$

which, in absolute value, will be strictly smaller than the true demand elasticity $\beta$. 


\section{Data AND Estimation Strategy}

\section{A. Reduced-Form Estimation}

The model summarized in Figure I raises an obvious reducedform test of whether there are external costs of adjustment. Namely, if the supply of capital is perfectly elastic-the standard assumption - then increasing tax subsidies should have no impact on the pretax price of capital. With external adjustment costs, on the other hand, increasing tax subsidies should directly increase capital goods prices. ${ }^{7}$

This paper will use the variations across time and across assets in investment tax incentives as instruments for short-run investment demand to determine whether they increase the prices of capital goods. The paper uses the contemporaneous tax term, $(1-I T C-t z) /(1-t)$, rather than the cost of capital generally because the latter may have large endogeneity problems, as has often been pointed out. ${ }^{8}$ The paper will present evidence that including the other parts such as interest, depreciation, and future tax changes, does not change the results. The paper will also present some results using only the ITC because it is the simplest possible instrument for investment demand: well understood, easily measured, and clearly applicable to current purchases.

The estimation strategy will be to examine whether the price of an asset depends on the rate of investment incentive for that asset. The basic specification for the real price of asset $i$ in year $t$ is

$$
\ln \left(P_{i t}\right)=\alpha_{i}+\theta_{i} t+\beta_{i} \cdot\left(\operatorname{tax}_{i t}\right)+\Gamma_{i}^{\prime} X_{t}+\epsilon_{i t},
$$

where $\alpha_{i}$ is a fixed effect for asset $i, t$ is a time trend whose effect can vary by asset or be zero depending on the specification, $\operatorname{tax}_{i t}$ is a measure of the tax term on asset $i$ in year $t$, and $X_{t}$ is some vector of annual covariates like the real exchange rate, the GDP growth rate, a variable for the Nixon price controls, or year dummies. The coefficients on the covariates, except for the year dummies, will usually be allowed to differ by asset, as well.

7. If investment subsidies, in addition to increasing the demand for capital suppliers' output, also reduce the capital suppliers' costs, this will bias the reduced-form coefficients downward. The empirical results below will show that prices rise significantly despite this downward bias.

8. For one discussion of endogeneity see Clark [1993] and the comments by Robert Hall and William Brainard in the general discussion. 


\section{B. Data}

Information on the dependent variable comes from two series of annual price indices for 1959-1988: capital equipment goods deflators for 22 asset types compiled by the Bureau of Economic Analysis in U. S. Department of Commerce [1993] and output deflators for 81 four-digit SIC code capital equipment producers in the NBER productivity data set described in Bartelsman and Gray [1996]. Both types of price data are divided by the GDP deflator to get the real price and are described in more detail in the Data Appendix. The broad categories are listed in Table II. The 22 asset types are directly comparable to the data on taxes and so are generally preferred. The 81 SIC codes, though, will enable the paper to use industry level data to identify the extent of rent-sharing, the importance of imports and capacity constraints, and the elasticity of the supply curve. Some of the results, therefore, will use these output deflators, despite the potential measurement error. The results are very similar between the two sources.

Information on the explanatory variables includes data on tax subsidies by asset type provided by Dale Jorgenson. This information is combined with the corporate tax rate to create the tax portion of equation (1), $(1-I T C-\tau z) /(1-\tau)$. The data are measured according to the methods described in Jorgenson and Yun [1991] and are outlined in the Appendix, as are the other data of this paper.

Figure II graphs the tax term for a few of the assets over time. The median tax term is 1.052 . There is time series variation, and although smaller, there is also variation between assets. The standard deviation across time for the median asset is .082, while the standard deviation across assets for the median year is .032 . The time series variation arises from changes to tax policy over time. The cross-sectional variation in the tax term comes about from both the depreciation allowances and the investment tax credit. Depreciation allowances are explicitly different for assets with different tax lives, generating clear variation across assets. But the ITC also varies by asset for many years in the sample. Motor vehicles and aircraft, for example, normally have lower rates of credit. The cross-sectional variation in the tax term changes over time, as well. 


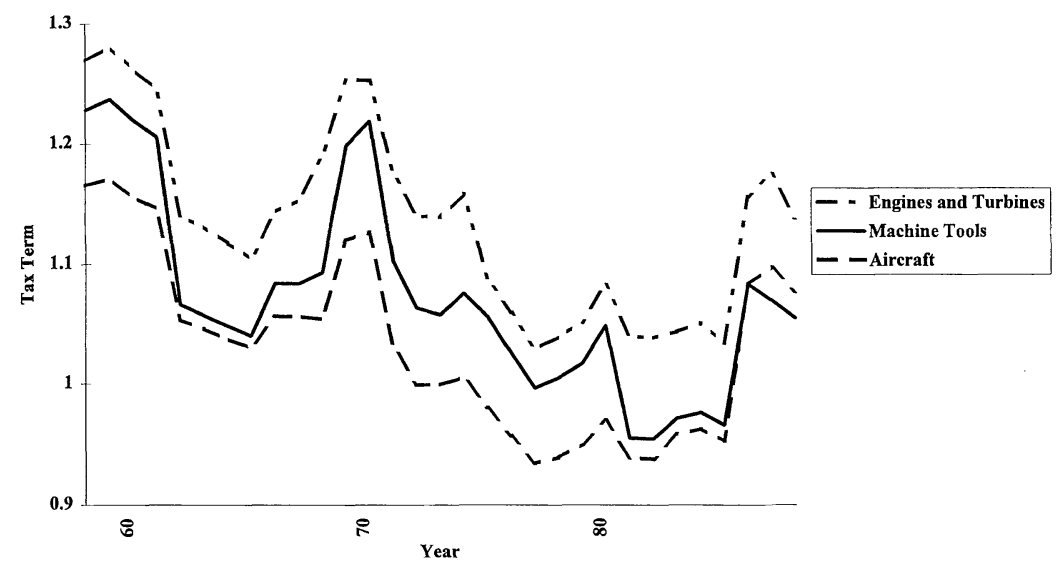

FIGURE II

Tax Term for Various Assets

\section{Reduced-Form Results: Evidence of Price InCReAses}

To show the standard specification, I estimate equation (6) for tractors alone as an example. The results are listed in Table I. The sample is 1959 to 1988 , and the dependent variable is the log of the real price index for tractors. The equation includes a measure of the tax subsidy, a time trend to account for relative productivity growth, the real exchange rate for marks and for yen, the GDP growth rate, and a variable accounting for the Nixon price controls from 1971-1974. ${ }^{9}$ This regression performs exactly the reduced-form test proposed above-testing whether subsidies raise prices. The tax coefficient is large and highly significant. The reduced-form magnitude indicates that a 10 percent ITC increases tractor prices by more than 6.5 percent.

Column (2) repeats the same regression but with the full tax term instead of just the ITC. The sign is reversed since a subsidy reduces the tax term. Once again, the coefficient is highly significant, and the magnitude large. In the full tax term, an ITC of 1 percent increases prices by $-\beta /(1-t)$ percent, so at the mean corporate tax rate of .48 , doubling the coefficient makes the magnitude roughly comparable to that in the ITC equation. For

9. The price controls were introduced by Nixon in August 1971 and repealed in April 1974. The variable is .33 in the partial years and 1 in 1972 and 1973 . Including separate year dummies for 1971-1974 did not change the results. Excluding the variable does not change any results in the paper except those on duration, as explained in footnote 12 . 
TABLE I

BASIC REGRESSION: TRACTORS

\begin{tabular}{lcc}
\hline \hline \multicolumn{1}{c}{ Variables } & $(1)$ & $(2)$ \\
\hline ITC & $.6519(.1412)$ & \\
Tax term & & $-.4350(.1096)$ \\
Exch marks & $-.0049(.0011)$ & $-.0046(.0012)$ \\
Exch yen & $-.0014(.0008)$ & $-.0023(.0010)$ \\
Time trend & $.0004(.0014)$ & $-.0003(.0015)$ \\
GDP growth & $-.0018(.0018)$ & $-.0028(.0020)$ \\
Price controls & $-.1300(.0142)$ & $-.1362(.0153)$ \\
Constant & $.4355(.0591)$ & $.9485(.1513)$ \\
$R^{2}$ & .96 & .95 \\
$\mathrm{n}$ & 30 & 30 \\
\hline \hline
\end{tabular}

The dependent variable is the log of the real price. Standard errors are in parentheses. The sample is 1959-1988. The Tax term variable is the contemporaneous tax component of the cost of capital as defined in the text.

tractors, a 10 percent ITC increases the price more than 8 percent. In both equations a sizable fraction of the benefit of tax subsidies does not go to the purchasers of the equipment but is instead capitalized into the price of the tractors. The other coefficients indicate that increasing the real value of the dollar reduces domestic prices, that the business cycle, as represented by the GDP growth rate, does not have a major impact, and that the price controls of 1971-1974 significantly reduced prices.

With this specification in mind, Table II presents the tax coefficients using all asset types. It fits the same equation as in Table I but estimates the coefficients jointly for the 22 assets using Seemingly Unrelated Regression (SUR) and quasi-differences each equation to correct for $\mathrm{AR}(2)$ serial correlation. Column (1) presents the coefficients using only the ITC, while column (2) uses the entire tax term.

In the ITC regressions, 13 of the 22 assets have substantial, positive, and significant tax coefficients, indicating that higher ITCs correspond to higher prices. Forty percent of the asset types have coefficients at or above .7 , meaning that a 10 percent ITC raises prices more than 7 percent. For these assets, tax incentives have very little impact on the after-tax cost of capital. In column (2), using the full tax term, 15 of the 22 assets have significant negative coefficients, indicating that higher subsidies raise prices. For 40 percent of the assets, the 10 percent ITC increases prices more than 8 percent. 
TABLE II

Tax Coefficients from Price Regressions by Asset Class

(STANDARD ERRORS IN PARENTHESES)

\begin{tabular}{|c|c|c|c|c|}
\hline Asset class & $\begin{array}{c}\text { ITC } \\
(1)\end{array}$ & $\begin{array}{l}\text { Tax term } \\
\text { (2) }\end{array}$ & $\begin{array}{c}\text { Tax term } \\
\text { (3) } \\
\text { Year } \\
\text { dummies }\end{array}$ & $\begin{array}{c}\ln (\text { tax term }) \\
(4)\end{array}$ \\
\hline 1. Furniture & $.0243(.1370)$ & $-.0244(.0768)$ & $.0431(.1014)$ & $-.0223(.0806)$ \\
\hline 2. Fabricated metals & $.7454(.1698)$ & $-.4134(.0726)$ & $-.3626(.1032)$ & $-.4409(.0772)$ \\
\hline 3. Engines & $.6637(.2479)$ & $-.3447(.1454)$ & $-.3314(.1459)$ & $-.3973(.1646)$ \\
\hline 4. Tractors & $.7101(.1328)$ & $-.4983(.1119)$ & $-.4999(.1043)$ & $-.5126(.1119)$ \\
\hline 5. Agric. machinery & $.9762(.1954)$ & $-.4849(.1120)$ & $-.4860(.1191)$ & $-.5220(.1162)$ \\
\hline 6. Constr. mach. & $.4813(.1445)$ & $-.2884(.0783)$ & $-.2638(.0706)$ & $-.3027(.0810)$ \\
\hline 7. Mining mach. & $1.674(.2431)$ & $-.8819(.1270)$ & $-.8744(.1462)$ & $-.9434(.1297)$ \\
\hline 8. Metalwrk. mach. & $.4316(.1830)$ & $-.1687(.0950)$ & $-.0977(.1227)$ & $-.1829(.1027)$ \\
\hline 9. Special ind. mach. & $.1497(.1391)$ & $-.0845(.0664)$ & $-.0147(.1029)$ & $-.0844(.0717)$ \\
\hline 10. General ind. mach. & $.2064(.1619)$ & $-.1301(.0829)$ & $-.0865(.0834)$ & $-.1339(.0873)$ \\
\hline 11. Office/computers & $-.7607(.4924)$ & $.4829(.2658)$ & $.8673(.2769)$ & $.5021(.2767)$ \\
\hline 12. Service ind. mach. & $.1246(.1117)$ & $-.0708(.0600)$ & $-.0082(.1026)$ & $-.0698(.0634)$ \\
\hline 13. Electrical distrib. & $.2599(.1829)$ & $-.1295(.0729)$ & $-.1201(.0878)$ & $-.1282(.0753)$ \\
\hline 14. Communication & $-.6034(.2098)$ & $.1833(.0918)$ & $.2565(.0933)$ & $.1910(.0946)$ \\
\hline 15. Electrical eqmnt. & $.8936(.1808)$ & $-.4294(.0922)$ & $-.3949(.1153)$ & $-.4706(.0959)$ \\
\hline 16. Trucks and buses & $.7874(.2299)$ & $-.4190(.1738)$ & $-.4741(.1999)$ & $-.4468(.1817)$ \\
\hline 17. Autos & $-.5834(.1940)$ & $.3406(.1286)$ & $.3747(.2209)$ & $.3489(.1289)$ \\
\hline 18. Aircraft & $1.010(.1836)$ & $-.5389(.1338)$ & $-.4762(.1484)$ & $-.5785(.1361)$ \\
\hline 19. Ships & $.5914(.1197)$ & $-.2060(.0553)$ & $-.1749(.0625)$ & $-.2243(.0601)$ \\
\hline 20. $R R$ equipment & $1.091(.1695)$ & $-.4858(.0805)$ & $-.5126(.0969)$ & $-.5337(.0849)$ \\
\hline 21. Instruments & $-.3491(.1718)$ & $.1637(.0899)$ & $.2338(.1158)$ & $.1738(.0935)$ \\
\hline 22. Other equipment & $.2952(.1524)$ & $-.2009(.0812)$ & $-.0994(.1050)$ & $-.2085(.0851)$ \\
\hline$R^{2}$ & $: 95$ & .98 & .98 & .98 \\
\hline Number obs. & 594 & 594 & 594 & 594 \\
\hline POOLED & $.3900(.0361)$ & $-.1700(.0280)$ & $-.1902(.0445)$ & $-.1774(.0221)$ \\
\hline
\end{tabular}

The dependent variable is the log of the real price using the asset deflators. Standard errors are in parentheses. The sample is 1962-1988. Each equation allows for a time trend, the real exchange rate of marks and of yen, the GDP growth rate, a price controls variable, and a constant term. The 22 equations are estimated jointly using seemingly unrelated regression, corrected for $A R(2)$ serial correlation in each equation by quasi-differencing. The pooled coefficient is estimated the same way but with the coefficient on the tax term restricted to be the same across equations. Only the coefficient on the tax term is listed. For column (1) this is the ITC; for columns (2) and (3) this is the contemporaneous tax term; and for column (4) this is the log of the tax term.

The industries with positive coefficients are basically the same for the two specifications. One of the interesting aspects of Table II is the heterogeneity in the price response across different types of assets. The industries with significant price increases are mainly fabricated metals, heavy machinery, and large transportation equipment (industries 2-8 and 15-20). The four industries with a perverse sign-computers, communication equipment, cars, and instruments-are the four assets with the largest 
downward time trends and ones where quality change has been most problematic for calculating price indices.

Below each column is the result where the assets are restricted to have the same price coefficient. In both cases a 10 percent ITC creates an overall price increase of around 3.5-4 percent. ${ }^{10}$ The coefficient is even greater when the four industries with quality problems are excluded. The basic reduced-form evidence, then, is quite clear. Prices rise substantially for a large number of assets in response to tax subsidies - a fact that is inconsistent with a perfectly elastic supply curve.

\section{Robustness to Alternative Explanations}

\section{A. Endogenous Tax Policy}

The first important alternative explanation of the results is that tax policy is endogenous, and this might be causing a spurious correlation between taxes and capital goods prices. Intuitively, though, this fact is working in the wrong direction to explain the results. Policy-makers try to enact investment subsidies when investment demand is low. This link is often used to explain why regressions of the quantity of investment on tax policy have small coefficients. Political histories of the investment subsidies such as King [1993] strongly reinforce the impression that macroeconomic conditions are the primary justification used by policy-makers who consistently stress that aggregate demand and investment are "too low" when they enact credits. Such a pattern, however, would mean that the coefficients in Table II actually underestimate the effect of the ITC on prices since high credits are passed when investment demand and price are depressed by the business cycle.

To explain the estimated coefficients, policy-makers would have to raise investment subsidies when prices are high. Further, the results allowed GDP growth and real exchange rates to affect prices, so the endogeneity must embody more than what is contained in those variables. To further eliminate the possibility of spurious correlation, however, column (3) uses the cross-asset variation in the tax term to identify the effect of subsidies while removing all aggregate variation through year dummies. It

10. An earlier version of this paper [Goolsbee 1996] showed that doing this regression in first differences rather than in levels requires a correction for measurement error but that the resulting estimates of the tax-induced price changes are even larger than those in Table II. 
TABLE III

\begin{tabular}{lccc}
\hline \hline & $(1)$ & $(2)$ & $(3)$ \\
& Prices & Wages & Wages-CPS \\
\hline $\mathrm{CAP} *$ tax term & -.1222 & -.0500 & -.1650 \\
& $(.0632)$ & $(.0248)$ & $(.0332)$ \\
$\mathrm{CAP} *$ time trend & .0051 & -.0007 & -.0012 \\
& $(.0013)$ & $(.0006)$ & $(.0009)$ \\
$\mathrm{CAP} *$ exch marks & .0003 & .0002 & \\
& $(.0001)$ & $(.0001)$ & \\
$\mathrm{CAP} *$ exch yen & -.0001 & -.0001 & .0014 \\
& $(.0001)$ & $(.0001)$ & $(.0008)$ \\
$\mathrm{CAP} *$ GDP growth & -.0019 & -.0013 & Yes \\
& $(.0018)$ & $(.0007)$ & .26 \\
Year dummies & Yes & Yes & 190,751 \\
$R^{2}$ & .68 & .94 & 13,500 \\
Number obs. & 13,500 & & \\
\hline \hline
\end{tabular}

The dependent variable in column (1) is the log of the real price using the NBER productivity data. In column (2) it is the log of the industry real hourly production wage using the NBER productivity data. In column (3) it is the log of the real wage using individual level CPS data described in the text. Standard errors are in parentheses. The sample period in columns (1) and (2) is 1959-1988, and in (3) is 1979-1988. CAP is a dummy variable equal to one for capital goods industries or workers. Columns (1) and (2) are fixed effect regressions on 450 industries. Column (3) estimates a wage equation including experience, experience squared, years of schooling, as well as marriage and race dummies whose coefficients are not listed.

repeats the SUR regression of column (1), again corrected for serial correlation in each equation and including equation-specific exchange rates, price control variables, and GDP growth, but now adds year dummies. Almost all the tax coefficients are very similar. Overall, a 10 percent ITC raises prices about 4 percent when year dummies are included-slightly higher than without year dummies.

Finally, Table III uses price data for all 450 manufacturing industries in the NBER productivity database, includes year dummies, and asks whether prices for the 81 capital equipment producers rise more during investment subsidies than prices rise for other manufactured goods in those same years. The regression does this by interacting with the tax term a capital goods dummy that is equal to one if the industry is a capital equipment producer. The regression also allows equipment producers to have a different time trend and a different responsiveness to GDP growth and real exchange rates. The results in column (1) show that even within manufacturing, relative prices rise for equipment producers in response to investment subsidies. A 10 percent ITC raises the relative price of equipment by almost 2.5 percent. 


\section{B. Interest and Depreciation}

Since the full cost of capital is the tax term times the sum of interest, depreciation, and expected inflation (see equation (1)), to the extent that the other terms covary systematically with the tax term, this could lead to bias. Column (4) of Table II assumes that the depreciation rate, the real interest rate, and expected inflation can differ by asset but are constant. Under these conditions, taking logs of the tax term yields a specification in which the tax term is additively separable from the other terms that are then fully captured in the asset fixed effects. The resulting coefficients on the log of the tax term are virtually identical. A 10 percent ITC at the mean level of the tax term raises prices by 3.5 percent. ${ }^{11}$ There is no evidence that the other components of the cost of capital are generating the results.

\section{Anticipation and Expectation}

Expected future tax policies also enter into the current cost of capital. Further, some of the changes in the tax code were announced before they took effect, so anticipation should clearly have been incorporated into the investment decision. Steigerwald and Stuart [1993], though, have argued that, empirically, investment demand does not behave as if firms have much information about future tax rates. Table IV uses both the actual value of future tax changes and a linear prediction of the tax term at time $t$ using information known at time $t-1$ to examine the impact that future tax changes have on capital equipment prices. The sample is restricted so as to be the same across the specifications.

Column (1) shows that the basic results on this sample are very similar to those above. A 10 percent ITC raises prices by 4.2 percent. Replacing the tax term with an expectation given information before time $t$, as in column (2), yields a negative and significant coefficient slightly larger than in (1) but basically the same. Column (3) shows that including the future value of the tax term does not have a significant nor a large coefficient, while the coefficient on the contemporaneous tax term remains important. A 10 percent ITC next period leads prices to rise by less than 1 percent today and not significantly. In the year of passage, however, prices rise 3.6 percent. Anticipation of future tax rates

11. A regression that repeated the specification of column (4) but included, as a separate term, the log of real interest plus next year's price inflation for the asset plus the depreciation rate for the asset yielded almost exactly the same coefficient on the tax term, so it is excluded for simplicity. 
TABLE IV

TAX CoEFFicien's With ANTICIPATION AND ExPECTATION

\begin{tabular}{|c|c|c|c|}
\hline $\begin{array}{l}\text { Independent } \\
\text { variables }\end{array}$ & (1) & (2) & (3) \\
\hline$E_{t-1}\left[T A X_{t}\right]$ & & $\begin{array}{c}-.2516 \\
(.0252)\end{array}$ & \\
\hline$T A X_{t}$ & $\begin{array}{c}-.2152 \\
(.0242)\end{array}$ & & $\begin{array}{r}-.1865 \\
(.0338)\end{array}$ \\
\hline$T A X_{t+1}$ & & & $\begin{array}{r}-.0434 \\
(.0352)\end{array}$ \\
\hline$R^{2}$ & .97 & .97 & .97 \\
\hline Number obs. & 616 & 616 & 616 \\
\hline
\end{tabular}

The dependent variable is the $\log$ of the real price. Standard errors are in parentheses. To keep the samples consistent across the specifications, the sample period is 1960-1987. There are 22 equations. Each equation allows for a time trend, the real exchange rate for marks and yen, the GDP growth rate, year dummies for price controls from 1971-1974 and a constant term. The equations are estimated jointly using seemingly unrelated regression, and the coefficient on the tax terms are restricted to be the same across equations.

does not seem to be a major factor in current investment demand while the current tax term does, so the results that follow will, again, look at the contemporaneous tax term as an instrument on its own.

\section{Further REsults: DuRATion AND InCidence}

\section{A. Duration}

The results imply that the supply of capital is not flat and that investment tax subsidies are capitalized into prices. Eventually, though, the price effect of a permanent tax subsidy should at least partially die out as the supply curve becomes more elastic and investment approaches the steady state. The problem with such an enterprise, as stated at the outset, is that tax policy is a poor instrument for long-run demand. Policy-makers do not leave tax subsidies alone for any substantial amount of time, so there are no permanent changes that can be examined. If policies are temporary, prices may rise with a subsidy but fall when the subsidy is repealed, and the economy may never actually reach the new steady state. In other words, there will be no information on what happens to prices after several years of subsidy. In such a case, the estimates will show large contemporaneous price effects, but the lagged terms will be poorly estimated.

Table V presents estimates from regressions that include lagged changes in the tax term to examine the dynamics of the 
TABLE V

DuRation of TAX CoEFFicients

(2)

Independent variable

Year dummies

\begin{tabular}{lcc} 
TAX TERM $_{t}$ & -.1667 & -.2346 \\
& $(.0251)$ & $(.0572)$ \\
TAX TERM $_{t-1}$ & -.0974 & -.0423 \\
& $(.0246)$ & $(.0583)$ \\
TAX TERM $_{t-2}$ & -.0405 & -.0268 \\
& $(.0265)$ & $(.0707)$ \\
TAX TERM $_{t-3}$ & -.0392 & .0243 \\
$R^{2}$ & $(.0338)$ & $(.0702)$ \\
Number obs. & .91 & .95 \\
& 616 & 616 \\
\hline
\end{tabular}

The dependent variable is the log of the real price using the asset deflators. Standard errors are in parentheses. Column (1) includes a time trend, the real exchange rate for marks and for yen, a price controls variable, a constant term, and the GDP growth rate with coefficients that vary by industry. Column (2) also includes year dummies. Only the coefficients on the tax terms are reported. The sample in both regressions is 1961-1988.

price responses to tax subsidies. Column (1) shows that, as expected, prices increase immediately following the tax change. The increase continues slightly for one more year and then stops. There is little evidence, however, that the prices come back down in the long run, and the standard errors on the lagged terms are very large. ${ }^{12}$ Adding more lags to the equation did not change the results. After three years, the sum of the coefficients is not significantly different from zero, so one cannot reject the hypothesis that the price increase has disappeared, but there appears to be little information that far out.

Column (2) presents the same regression but including year dummies. Now the entire price increase is in the contemporaneous year but again the prices never actually seem to fall back down. Here, after two years the sum of the coefficients is not significantly different from zero. The evidence, then, on how long the price increases last is not clear. After two to three years the point estimates are still positive, but the sum is not significant because the standard errors get so large. It is quite clear, however, that prices increase immediately following a subsidy as the theory would predict, making the short-run price effects of key importance.

12. The duration regression is the only one where accounting for the Nixon price controls significantly changes the results. In 1972 and 1973 the relative price of capital fell significantly because of the price controls, but the ITC was repealed in 1969. Without the control variable, this outlier year induces a large coefficient on the tax term lagged three and four years. 


\section{B. Incidence}

From a public finance/incidence perspective, the results above indicate that only about 60 percent of investment subsidies go to the buyers, with the remaining 40 percent going to capital suppliers. Within the 40 percent, however, workers may receive part of the gains through higher wages. Columns (2) and (3) of Table III examine the response of real wages for capital goods workers in response to subsidies. Column (2) looks at all 450 manufacturing industries in the NBER productivity database and asks whether the real hourly production wages of the 81 equipment-producing SIC codes rise relative to other manufacturing workers in periods of investment subsidies. Just as in the regression with prices of column (1), this regression looks at the impact of the tax term interacted with a capital goods worker dummy while including year dummies. It also allows for capital goods industries to have a separate time trend and to react differently to GDP growth and to real exchange rates. The coefficient indicates that the wages of capital goods workers rise significantly when there are investment subsidies. A 10 percent ITC raises the wage of capital goods workers by about 1 percent relative to other manufacturing workers in the same year. Furthermore, this estimate has a potentially serious downward bias due to changes in the composition of workers within these industries as described in Goolsbee [1997]. That paper looked at Current Population Survey (CPS) data to control for individual attributes and showed a significant impact of investment subsidies on capital goods worker wages and showed how it varies by educational attainment, occupation, experience, and union status.

Column (3) presents a more detailed micro regression in the spirit of Goolsbee [1997] using the CPS Merged Outgoing Rotation Group data described in Feenberg [1995]. It fits a traditional equation for real weekly earnings which includes education, experience (defined as age minus education minus six), experience squared, and race and marital status dummies. It also includes year dummies, a capital goods worker dummy, and interactions of the capital goods dummy with a time trend, GDP growth, and the tax term. The data cover full-time, male manufacturing workers from 1979-1988. The coefficient on the tax term shows that wages rise significantly for capital goods workers relative to other manufacturing workers with identical observables during years of investment subsidies. The coefficients on individual characteristics are not reported for simplicity. A 10 percent ITC raises the 
wage of capital goods workers by 3.2 percent relative to an identical noncapital goods worker.

From these wage regressions it is clear that capital goods workers do share in the benefits of capital subsidies-perhaps as a form of rent sharing. ${ }^{13}$ Taking the wage rise as 3.2 percent and labor's share of gross output at 30 percent, the approximate incidence of investment subsidies is 60 percent to buyers, 30 percent to capital suppliers, and 10 percent to capital goods workers.

\section{Further Results: Causes of Heterogeneity}

The original results showed considerable heterogeneity between assets in their price responsiveness to tax changes. The results that follow, by directly tying the heterogeneity to observable industry factors, further substantiate the upward-sloping supply curve hypothesis. The results, presented in Table VI, are based on fixed effects regressions for the output prices of the 81 equipment-producing industries in the NBER data. Each regression is a variant of the base specification in column (1) which includes the tax term real exchange rates, GDP growth, a time trend, and the price control variable. The tax coefficient in that column is -.29 , somewhat larger than the coefficients estimated previously. From this starting point, there are three basic causes of heterogeneity.

\section{A. Potential Users of Tax Subsidies}

The first explanation of the heterogeneous coefficients deals with the share of buyers who can use investment tax subsidies. Not all buyers can. Some may be in tax loss positions. Others may be in nontaxed sectors like the government. Obviously, prices should be more responsive to subsidies where more buyers can use them. Unfortunately, it is impossible to calculate the exact percentage of firms that can use tax subsidies in a given year. As described in the Appendix, though, using input-output tables, it is possible to calculate the percentage of output that is sold to sectors that definitely cannot use investment tax subsidiespersonal consumption, exports, and the government-for most of

13. Goolsbee [1997] finds that union status is an important determinant of the wage response to tax subsidies and argues that, therefore, part of the wage increases may be due to rent-sharing rather than simply a scarcity of production labor. 
TABLE VI

Causes of Price Response

\begin{tabular}{|c|c|c|c|c|c|c|}
\hline $\begin{array}{l}\text { Independent } \\
\text { variables }\end{array}$ & (1) & (2) & (3) & (4) & (5) & (6) \\
\hline TAX & $\begin{array}{c}-.2932 \\
(.0694)\end{array}$ & $\begin{array}{c}.3003 \\
(.1304)\end{array}$ & $\begin{array}{c}-.5506 \\
(.0797)\end{array}$ & $\begin{array}{c}-.4516 \\
(.0779)\end{array}$ & $\begin{array}{l}.1634 \\
(.0649)\end{array}$ & $\begin{array}{l}.0217 \\
(.0631)\end{array}$ \\
\hline TAX $*$ SHARE & & $\begin{array}{c}-.6915 \\
(.1624)\end{array}$ & & & & \\
\hline TAX $*$ AVG IMP & & & $\begin{array}{l}4.162 \\
(.6481)\end{array}$ & & & \\
\hline $\mathrm{TAX} * \mathrm{IMPORT}_{t-1}$ & & & & $\begin{array}{l}2.774 \\
(.5465)\end{array}$ & & \\
\hline TAX $*$ AVG. TIGHT & & & & & $\begin{array}{c}-.5031 \\
(.0870)\end{array}$ & \\
\hline $\mathrm{TAX} * \mathrm{TIGHT}_{t-1}$ & & & & & & $\begin{array}{l}-.2016 \\
(.0819)\end{array}$ \\
\hline IMPORT $_{t-1}$ & & & & $\begin{array}{r}-3.055 \\
(.5610)\end{array}$ & & \\
\hline TIGHT $_{t-1}$ & & & & & & $\begin{array}{c}.2052 \\
(.0855)\end{array}$ \\
\hline Exch marks & $\begin{array}{l}-.0003 \\
(.0001)\end{array}$ & $\begin{array}{c}-.0004 \\
(.0001)\end{array}$ & $\begin{array}{l}-.0003 \\
(.0001)\end{array}$ & $\begin{array}{c}-.0003 \\
(.0001)\end{array}$ & $\begin{array}{c}-.0003 \\
(.0001)\end{array}$ & $\begin{array}{c}-.0003 \\
(.0001)\end{array}$ \\
\hline Exch yen & $\begin{array}{c}-.0004 \\
(.0008)\end{array}$ & $\begin{array}{c}-.0001 \\
(.0001)\end{array}$ & $\begin{array}{l}-.0000 \\
(.0001)\end{array}$ & $\begin{array}{c}-.0001 \\
(.0001)\end{array}$ & $\begin{array}{l}-.0002 \\
(.0001)\end{array}$ & $\begin{array}{r}-.0001 \\
(.0001)\end{array}$ \\
\hline Time trend & $\begin{array}{l}-.0118 \\
(.0015)\end{array}$ & $\begin{array}{l}-.0087 \\
(.0008)\end{array}$ & $\begin{array}{l}-.0117 \\
(.0014)\end{array}$ & $\begin{array}{c}-.0112 \\
(.0015)\end{array}$ & $\begin{array}{c}-.0077 \\
(.0010)\end{array}$ & $\begin{array}{r}-.0075 \\
(.0010)\end{array}$ \\
\hline Price controls & $\begin{array}{r}-.0643 \\
(.0154)\end{array}$ & $\begin{array}{r}-.0925 \\
(.0089)\end{array}$ & $\begin{array}{r}-.0645 \\
(.0152)\end{array}$ & $\begin{array}{r}-.0690 \\
(.0153)\end{array}$ & $\begin{array}{c}-.0833 \\
(.0095)\end{array}$ & $\begin{array}{c}-.0816 \\
(.0096)\end{array}$ \\
\hline GDP growth & $\begin{array}{c}-.0027 \\
(.0020)\end{array}$ & $\begin{array}{l}-.0016 \\
(.0011)\end{array}$ & $\begin{array}{l}-.0025 \\
(.0020)\end{array}$ & $\begin{array}{c}-.0033 \\
(.0020)\end{array}$ & $\begin{array}{l}-.0005 \\
(.0012)\end{array}$ & $\begin{array}{r}-.0006 \\
(.0013)\end{array}$ \\
\hline$R^{2}$ & .37 & .34 & .38 & .38 & .33 & .32 \\
\hline Number obs. & 2430 & 1980 & 2430 & 2430 & 1566 & 1566 \\
\hline
\end{tabular}

The dependent variable in each column is the log of the real price from the NBER productivity data for 81 capital equipment industries. Standard errors are in parentheses. The sample is 1959-1988 in (1)-(4) and 1959-1985 in (5)-(6). SHARE is the share of demand that can potentially use the TAX as described in the text. IMPORT percent is the previous year's import ratio as described in the text. TIGHT is the ratio of unfilled orders to shipments at the end of the previous year as described in the text. AVG indicates an average over the sample.

the industries. Using the share not sold to those three sectors as a proxy for the potential share of demand capable of using a subsidy, column (2) interacts this share with the tax term and puts it in the standard panel regression for the assets that have data. The interaction term has a negative coefficient independent of the tax term alone indicating that tax subsidies have a larger impact the larger is the potential share of subsidy users. A 10 percent ITC for an industry with a share of potential subsidy users at the top 
quartile (90 percent potential users) would raise prices by 6.4 percent. An ITC for an asset with potential demand at the lowest quartile level (67 percent potential users) would increase prices about 3 percent.

\section{B. Imports}

Some of the capital goods in question are highly traded, and import competition is intense. The greater the world supply of a capital good, the more elastic should be the supply curve and the smaller the price response to tax subsidies. Using import data from the NBER import database described in Feenstra [1996], I create a simple measure of import share which is the ratio of imports to domestic output plus imports. To get around possible simultaneity issues associated with the current year, column (3) interacts the tax term with the average import share over the entire sample, and column (4) interacts it with the import share from the previous year. In both cases, the interaction is important and indicates that higher import shares correspond to smaller increases in the prices of capital goods following tax changes. In column (3) a 10 percent ITC raises prices by 7 percent for the median industry but not at all for industries with import shares in the top decile. Column (4) shows the same pattern. Import competition does indeed "flatten" the supply curve.

\section{Capacity Constraints}

Capacity constraints may be a likely cause of rising marginal costs for equipment producers. I construct a general measure of capacity constraints in an industry as the ratio of unfilled orders to shipments. These data are available for 13 of the 22 classes of equipment from 1959-1984 using the Census Bureau's Manufacturing, Shipments, Inventories, and Orders [U. S. Bureau of the Census, 1960-1988] as described in the Appendix. To get around simultaneity problems in the current year, column (5) uses the average over the entire sample, and column (6) uses the ratio at the end of the previous year. Each regression interacts the measure of "tightness" with the tax term. As expected, the interaction term has a sizable and significant negative coefficient, indicating that the greater the backlogs, the more prices for an asset increase with a tax subsidy. Moreover, in column (6) the tax term alone has no significant effect, indicating that all of the heterogeneity in the price response between assets can be explained by the differing levels of backlogged orders. At the mean 
level of "tightness," prices rise by about 1 percent, but at the top decile they rise more than 8 percent.

Potential subsidy use, import competition, and limited capacity go a long way toward explaining the dispersion in price responses among different assets. Assets with low shares of potential users, low backlogs, or high import competition include furniture, computers, service industry machinery, electrical distribution equipment, communications, cars, and instruments. Assets with high potential user shares, large backlogs, or low imports include mainly heavy machineries and large transportation equipment. This corresponds directly to the assets' coefficients in Table II. It is also highly suggestive of an upward-sloping supply for capital.

\section{Estimating a Supply Curve for Capital}

The reduced-form evidence that prices rise in response to subsidies can be thought of as the first stage of a two-stage least squares estimate where investment subsidies serve as an instrument for investment demand. In theory, one could regress the quantity supplied for each asset on the price of capital, instrumented with asset-specific tax credits, to structurally estimate a supply curve for each type of capital. The problem is that although the reduced-form results show a significant role for tax policy on prices, the tax changes explain only a small part of the total price variation, and the resulting supply curves, based on 30 observations each, have very large standard errors. For most of the assets one cannot reject that the supply curve is completely inelastic nor that it is extremely flat. Instead, Table VII will use the panel of 81 SIC codes together and assume that the supply elasticity is the same across all assets.

The supply equation estimated is the log of real shipments of the capital good regressed on the log real price, asset fixed effects, asset-specific time trends, the price controls variable, sometimes the real wage, and sometimes year dummies. Prices are the only endogenous variable, and the demand instruments used to identify prices are the current and once lagged tax terms. ${ }^{14}$ Since the variables are in logs, the coefficient is the elasticity. In the most basic specification of column (1), the elasticity is estimated to be

14. To whatever extent investment subsidies reduce capital producers' costs, this will tend to bias the results toward finding the supply curve more elastic than it really is. 
TABLE VII

CAPITAl Equipment SuPply CuRve

\begin{tabular}{lcccccc}
\hline \hline Independent variables & $(1)$ & $(2)$ & $(3)$ & $(4)$ & $(5)$ & $(6)$ \\
\hline $\ln P$ & 1.141 & .7284 & 1.353 & 1.735 & .6246 & 1.090 \\
& $(.5050)$ & $(.4801)$ & $(1.155)$ & $(1.164)$ & $(4.025)$ & $(4.146)$ \\
$\ln P_{t-1}$ & & & & & 1.054 & 1.076 \\
& & & & & $(6.177)$ & $(6.566)$ \\
$\ln P_{t-2}$ & & & & & .2268 & .0688 \\
& & & & & $(3.669)$ & $\frac{(3.879)}{2.234}$ \\
Medium-run elasticity & & & & & $\mathbf{1 . 9 0 5}$ & $\mathbf{2 . 2 3 4})$ \\
$\quad$ (sum of coefficients) & & & & & $(\mathbf{1 . 3 1 5})$ \\
$\ln w$ & & .3619 & & .1951 & & .1732 \\
& & $(.0629)$ & & $(.0815)$ & & $(.0968)$ \\
Price controls & .1842 & .1441 & - & - & - & - \\
& $(.0390)$ & $(.0375)$ & & & & \\
Year dummies & no & no & yes & yes & yes & yes \\
Asset trends & yes & yes & yes & yes & yes & yes \\
Industry dummies & yes & yes & yes & yes & yes & yes \\
$R^{2}$ & .96 & .96 & .96 & .96 & .96 & .96 \\
Number obs. & 2430 & 2430 & 2430 & 2430 & 2187 & 2187 \\
\hline \hline
\end{tabular}

The dependent variable in each column is the log of real output. Standard errors are in parentheses. The sample is 1959-1988 for columns (1)-(4) and 1962-1988 in (5)-(6). Columns (1)-(4) are estimated using IV with the current and once lagged tax terms as instruments for price. Columns (5)-(6) include the current tax term and four lags. Columns (3)-(6) include year dummies. $P$ is the real price, and $w$ is the real annual wage for the capital producing industry.

1.14 with a confidence interval from, essentially, zero to two. In (2), which also includes the log of the average real annual earnings in the industry (from the NBER productivity data), the elasticity is around three-fourths and is not significantly different from one. ${ }^{15}$

Because there could be a variety of concurrent macroeconomic factors at work, columns (3) and (4) repeat the regressions above but include year dummies. These equations are identified off of the variation in the tax term between assets within years. The estimated supply elasticities are around 1.35 without wages and 1.75 with wages. Because there is less variation, the standard errors are larger, but the elasticities are again close to one. Although these estimates are only a first pass, none of the

15. Shea [1993] uses an innovative method to find demand instruments with input-output tables and estimates supply curves for several industries including aircraft and construction equipment. His estimates of the elasticity for these two equipment-producing industries, however, are less than zero. It is not clear why they differ from the results presented here. 
magnitudes is anywhere close to justifying the standard assumption of a perfectly elastic supply.

To demonstrate how important these supply elasticities are for estimating investment demand, take the standard estimates of investment demand elasticities which assume a flat supply curve-normally zero to - .4-and ask whether the supply curves estimated here can explain why the literature finds such small effects. We know that the share of a subsidy passed through to the supplier in a competitive market is equal to $-\eta_{D} /\left(\eta_{S}-\eta_{D}\right)$, where $\eta_{D}$ and $\eta_{S}$ are the elasticities of demand and supply. The reducedform price regressions for these 81 SIC codes indicated that a 10 percent ITC raised prices by about 5.6 percent or 56 percent pass through to the supplier. The estimates of the supply elasticities ranged from .75 to 1.75. Plugging this into the formula, the implied elasticity of investment demand ranges from -.95 to -2.15 with the average, in absolute valve, comfortably above 1 . In other words, by taking upward-sloping supply into account, the entire "puzzle" of the small estimated elasticity disappears.

To explore the dynamics of the supply curve, columns (5) and (6) include lags of the price, instrumented with further lags of the tax term. The price terms are, individually, estimated very imprecisely although the sum after three years is estimated fairly well. The point estimates indicate that the supply curve does expand over time, though not dramatically. It begins close to 1 and moves to about 2 after two years. Looking at time horizons beyond this, the cumulative estimate does not increase much, but the standard errors get substantially larger. In many ways, these are just structural versions of the reduced-form results on duration that did not find very strong evidence that prices fall within two or three years.

\section{CONCLUSION}

This paper has presented evidence from disaggregated asset price data for capital that suggests that investment tax incentives lead to immediate increases in the price of capital. The estimates from most specifications imply that a 10 percent ITC increases prices 3.5-7 percent with even larger increases for particular assets. These results are very robust. The price increases are greatest in industries where a large fraction of the customers can use investment subsidies, where import competition is low, and where there are high levels of backlogged orders. The price 
increases seem to last at least two or three years. The relative wages of capital goods workers rise under investment subsidies, as well.

Using the tax subsidies as instruments for investment demand to actually estimate a supply curve for capital puts the short-run elasticity at around 1 which increases to around 2 after two years. Such a supply curve can easily explain the small estimated effects of tax policy on real investment in conventional studies. In absolute value, the elasticity of demand implied here is greater than 1 .

The findings of this paper are some of the first direct evidence on the existence of adjustment costs external to the firm (see Mussa [1977] and Chirinko [1993] for a discussion) and bring attention to important general equilibrium "bottleneck" effects in aggregate investment as described in Caballero [1997]. The results may also lead to questions about our views on investment. It is commonly argued, for example, that a temporary ITC, while not increasing the long-run capital stock, can substantially increase short-run investment by diverting it into the current period (see Abel [1982] for a discussion). If the supply of capital goods is upward sloping, however, the primary effect may simply be temporarily higher prices.

Indeed, the results are most disturbing for the ongoing debate over investment tax policy. In addition to their large revenue costs, investment tax subsidies may give large, unintended rents to capital suppliers without increasing real investment until several years later because of the short-run asset price responses of capital goods. For policy-makers interested in using tax policy to stimulate investment or, especially, to smooth business cycle fluctuations, the results are not promising.

\section{DATA APPENDIX}

The tax data by asset were provided by Dale Jorgenson and are based on the methods described in Jorgenson and Yun [1991]. The investment tax credit and the corporate tax rate are easily measured in the tax law. Depreciation allowances depend on the cost of the asset, the salvage value, and the asset life as defined for tax purposes and, in theory, are also specified by law. In practice, however, prior to the 1980 s there was considerable flexibility in the asset lives claimed for tax purposes. Jorgenson and Yun [1991] use methods in Jorgenson and Sullivan [1981] to compute the 
implied asset lives for tax purposes by finding the asset life that makes their accounting formula for depreciation claims fit the historical series of actual claimed allowances (assuming various salvage values, and so on). To get the net present value of these allowances, they use the Baa bond rate.

The data on price deflators by asset are compiled by the BEA in Fixed Reproducible Tangible Wealth in the United States: 1925-1989. The output price deflators by four-digit SIC code come from the NBER productivity database (as do industry level wages and shipments). The data encompass 450 manufacturing industries, 81 of which are equipment-producing. Further detail on the data can be found in Bartelsman and Gray [1996]. Both price indices data are based on weighted averages of major component goods whose unit prices are kept by the Bureau of Labor Statistics in the Producer Price Index. The BLS data come from systematic sampling of the multiple producers of each good, are voluntarily provided by survey respondents, and are based on transaction rather than list prices. Changes in the taxation of goods are not reflected in the PPI as price changes. The producers must explicitly raise their prices.

To deal with quality changes, the BLS subtracts out the change in production cost for a new good using survey data on costs or else collects price data on the new and old good in the first period and defines the value of the quality change to be that difference. For details on BLS procedures see Chapter 16 in the BLS Handbook of Methods [1992]. The quality adjustment methods are probably worst for computers, automobiles, communications equipment, and scientific instruments, which also have the largest downward time trends in prices.

For imports, the NBER productivity data are matched to the NBER imports and exports database which gives the cost including freight of imports at the same level of detail for the same sample period. For potential users of investment subsidies, the data are matched to the share of output for a particular four-digit SIC code industry which is not sold for personal consumption, for export, or to the government. This information is compiled in Manufacturing U.S. A. [Darney 1994] for about 80 percent of the industries and is based on the 1982 input-output table and therefore fixed over time. For capacity constraints, the data are matched to the ratio of backlogged orders at the end of the previous year to shipments as listed in Manufacturers'Shipments, Inventories, and Orders. These data are available for 13 of the 22 
classes of assets. SIC codes within an industry group are assumed to have the industrywide ratio of backlogs to shipments for matching purposes. The data can be used only from 1959-1984 because of a change in the benchmarking which causes a large discrete jump starting in 1985. For details on the change see the discussion in Manufacturers' Shipments, Inventories, and Orders: 1982-1988.

The real exchange rates for marks and yen are calculated using nominal exchange rate and price level data in International Financial Statistics and the Economic Report of the President.

UnIVERSity of Chicago Graduate School of Business,

AMERICAN BAR FOUNDATION, AND THE

NATIONAL BUREAU OF ECONOMIC RESEARCH

\section{REFERENCES}

Abel, Andrew, "Investment and the Value of Capital," Massachusetts Institute of Technology, Ph.D. thesis, 1978.

, "Dynamic Effects of Permanent and Temporary Tax Policies in a $q$ Model of Investment," Journal of Monetary Economics, IX (1982), 353-373.

Auerbach, Alan, and Kevin Hassett, "Investment, Tax Policy, and the Tax Reform Act of 1986," in Do Taxes Matter? J. Slemrod, ed. (Cambridge, MA: MIT Press, 1990), pp. 13-49.

Auerbach, Alan, and Kevin Hassett, "Tax Policy and Business Fixed Investment in the United States," Journal of Public Economics, XLVII (1992), 141-170.

Bartelsman, Eric, and Wayne Gray, "The NBER Manufacturing Productivity Database," NBER Technical Working Paper 205, Cambridge, MA, October 1996.

Bosworth, Barry, "Taxes and the Investment Recovery," Brookings Papers on Economic Activity, 1 (1985), 1-38.

Caballero, Roberto, "Aggregate Investment: A 90's View," Handbook of Macroeconomics, John Taylor and Michael Woodford, eds. (Elsevier: North-Holland, forthcoming 1998).

Chirinko, Robert, "Business Fixed Investment Spending: A Critical Survey of Modeling Strategies, Empirical Results, and Policy Implications," Journal of Economic Literature, XXXII (1993), 1875-1911.

Chirinko, Robert, Steven Fazzari, and Alan Meyer, "What Do Micro Data Reveal about the User Cost Elasticity: New Evidence on the Responsiveness of Business Capital Formation," Emory University, unpublished, 1996.

Clark, Peter, "Tax Incentives and Equipment Investment," Brookings Papers on Economic Activity, 1 (1993), 317-348.

Cummins, Jason, Kevin Hassett, and R. Glenn Hubbard, "A Reconsideration of Investment Behavior Using Tax Reforms as Natural Experiments," Brookings Papers on Economic Activity, 2 (1994), 1-59.

Cutler, David, "Tax Reform and the Stock Market: An Asset Price Approach," American Economic Review, LXXVIII (1988), 1107-1117.

Darnay, Arsen, editor, Manufacturing U.S.A.: Industry Analyses, Statistics, and Leading Companies, 4th edition (Detroit, MI: Gale Research, 1994).

Economic Report of the President, 1996 (Washington, DC: U. S. Government Printing Office, 1996).

Feenberg, Daniel, "CPS Labor Extracts," NBER mimeo. 1995.

Feenstra, Robert, "U. S. Imports 1972-1994: Data and Concordances," NBER Working Paper No. 5515, Cambridge, MA, March 1996.

Feldstein, Martin, "The Surprising Incidence of a Tax on Pure Rent: A New Answer to an Old Question," Journal of Political Economy, LXXXV (1977), 349-360. 
Foley, Duncan, and Miguel Sidrauski, "Portfolio Choice, Investment and Growth," American Economic Review, LX (1970), 44-63.

Goolsbee, Austan, "Investment Tax Subsidies and Imperfect Competition: The Case of Machine Tools," University of Chicago, unpublished, 1995.

"Investment Tax Subsidies and the Price of Capital Goods," University of Chicago, unpublished, 1996.

"The Incidence of Investment Tax Subsidies: To the Workers Go the Spoils?" University of Chicago, unpublished, 1997.

Gordon, Roger, and Dale Jorgenson, "Policy Alternatives for the Investment Tax Credit," in Joint Seminars on Encouraging Capital Formation through the Tax Code, Committee on the Budget, U. S. Senate, $9 / 18 / 75$ (Washington, DC: U. S. Government Printing Office, 1975), pp. 15-84.

Gravelle, Jane, "Tax Subsidies for Investment: Issues and Proposals," Congressional Research Service Report 93-209, 2/21/92 (Washington, DC: U. S. Government Printing Office, 1992).

Hall, Robert, and Dale Jorgenson, "Tax Policy and Investment Behavior," American Economic Review, LIX (1967), 388-401.

International Monetary Fund, International Financial Statistics (Washington, DC, 1959-1989), various issues.

Jorgenson, Dale, and Martin Sullivan, "Inflation and Corporate Capital Recovery," in Depreciation, Inflation, and the Taxation of Income from Capital, C. Hulten, ed. (Washington, DC: Urban Institute Press, 1981).

Jorgenson, Dale, and Kun-Young Yun, Tax Reform and the Cost of Capital (Oxford: Oxford University Press, 1991).

King, Ronald, Money, Time, and Politics: Investment Tax Subsidies and American Democracy (New Haven, CT: Yale University Press, 1993).

Kopcke, Richard, "Forecasting Investment Spending: The Performance of Statistical Models," New England Economic Review (November/December 1982), 13-32.

Lucas, Robert, "Adjustment Costs and the Theory of Supply," Journal of Political Economy, LXXV (1967), 321-334.

Lyon, Andrew, "How Do Stock Prices Change When Corporate Tax Laws Change? An Empirical Analysis of the Effect of Tax Laws on the Value of the Firm," Princeton University, Ph.D. thesis, 1986.

Mussa, Michael, "External and Internal Adjustment Costs and the Theory of Aggregate and Firm Investment," Economica, XLIV (1977), 162-178.

Poterba, James, "Tax Subsidies to Owner-Occupied Housing: An Asset Market Approach," Quarterly Journal of Economics, XCIX (November 1984), 729-752.

Romer, David, Advanced Macroeconomics (New York: McGraw-Hill, 1996), Chapter 8.

Rosen, Sherwin, and Robert Topel, "Housing Investment in the United States," Journal of Political Economy, XCVI (1988), 718-740.

Shea, John, "Do Supply Curves Slope Upward?" Quarterly Journal of Economics, CVIII (1993), 1-32.

Steigerwald, Doug, and Charles Stuart, "Econometric Estimation of Policy Foresight: Taxes and Investment in the U. S." University of California, Santa Barbara, unpublished, 1993.

Summers, Lawrence, "Taxation and Corporate Investment: A ' $q$ ' Theory Approach," Brookings Papers on Economic Activity, 1 (1981), 67-127.

"The Asset Price Approach to the Analysis of Capital Income Taxation," Proceedings of the National Tax Association (Columbus, OH: National Tax Association, 1983), pp. 112-120.

U. S. Bureau of the Census, Manufacturers' Shipments, Inventories and Orders (Washington, DC: U. S. Government Printing Office, 1960-1988), various issues.

U. S. Department of Commerce, Bureau of Economic Analysis, Fixed Reproducible Tangible Wealth in the United States: 1925-1989 (Washington, DC: U. S. Government Printing Office, 1993).

U. S. Department of Labor, BLS Handbook of Methods; September, Bulletin 2414 (Washington, DC: U. S. Government Printing Office, 1992). 